\title{
Anomalies in the application of law related to hate crimes
}

\author{
ERIK USZKIEWICZ*
}

ELTE University, Faculty of Law, Hungary

\section{ORIGINAL RESEARCH PAPER}

Received: February 17, 2020 • Revised manuscript received: October 30, 2020 • Accepted: November 30, 2020 Published online: August 14, 2021

(c) 2020 The Author(s)

\begin{abstract}
The number of hate crime cases in certain countries that was brought to the authorities' attention and was included in the official statistics of countries and relevant international organizations could be negligibly low. However, alternative databases do not provide such a serene landscape as these data sets aim to provide a more credible picture of the real volume of hate crimes. The results of the victim surveys conducted amongst members of the potential victim groups can be even more shocking. Now it is obvious that only a small number of these crime cases is officially reported and behind the high latency, numerous personal and institutional causes can be identified, most notably in relation to victims and law enforcement authorities. The main objective of this literature review is to present these reasons and barriers that authorities are facing, difficulties of enforcement in individual cases and the significant structural problems in the application of law.
\end{abstract}

\section{KEYWORDS}

hate crimes, latency, jurisdictional practice, law enforcement, police, individual causes, institutional causes

\footnotetext{
*Corresponding author. E-mail: uszerik@gmail.com

The present paper was authored in the framework of the MTA-ELTE Lendület SPECTRA Research Group (Social prerequisites for the effective fight against bias-motivated crimes through criminal law and minority rights protection, contract number: LP2018-9/2018).
} 


\section{INTRODUCTION}

One of the biggest problems when talking about anomalies related to hate crimes, is the high associated latency. The present paper will explore the reasons behind this phenomenon. ${ }^{1}$

In many countries, in terms of official statistics, ${ }^{2}$ hate crimes seem to be a marginal in relation to the total number of crimes. In some states, the number of cases was brought to authorities' attention and thus appearing in the official statistics of countries and relevant international organizations, could be negligibly low. However, alternative databases, using different methods, do not provide such a serene landscape as these data sets try to provide a more credible picture of the real volume of hate crimes. The results of the victim surveys conducted amongst members of the potential victim groups can be particularly shocking. ${ }^{3}$ These databases and research results show that even in those European countries, where the operation of the official statistical system works relatively well, only a fraction of hate crimes reach the authorities. ${ }^{4,5}$ Unfortunately, only a small number of these crimes are officially reported in states where authorities, for various reasons, do not handle the phenomenon according to their severities. These reasons that contribute to high latency will be discussed in this paper.

Behind the high latency of hate crimes, numerous personal causes can be identified, most notably in relation to the victim and institutional causes, especially by law enforcement authorities. This paper firstly summarizes the personal causes and then goes into a more detailed analysis of the institutional ones. The sequence does not reflect any hierarchical relationship between the causes. This approach was taken in order to sensitively present the institutional reasons behind the high latency, which are inextricably linked to personal reasons.

\section{INDIVIDUAL CAUSES ${ }^{6}$}

The first step requires the emphasis of the relevance and inevitable role of the injured party (typically the victim) who must recognize that their right guaranteed by law has been infringed or there was an imminent threat of harm. This recognition presupposes dual knowledge: the individual has to be aware of the piece of law governing the relevant situation and that they are also familiar with the norm's content, 'knowledge of the norm' and 'knowledge of its content' - legal knowledge. ${ }^{7}$ The individual must therefore know, or at least assume, that there

\footnotetext{
${ }^{1}$ The author is grateful to Prof. Petra Bárd for her valuable comments on earlier versions of this article.

${ }^{2}$ OSCE ODIHR Hate Crime Reporting, link 1.

${ }^{3}$ Kesteren (2016).

${ }^{4}$ (FRA) Making hate crime visible in the European Union: acknowledging victims' rights, link 2.

${ }^{5}$ (FRA) Hate crime recording and data collection practice across the EU, link 3.

${ }^{6}$ Regarding personal reasons see also, Uszkiewicz (2013a).

${ }^{7}$ Bencze and Vinnai (2012) 15.
} 
is a contradiction between the text of the norm and thus the desired behavior, and the real-life situation. In case of hate crimes this means that the violent act is a crime (this is relatively clear), however the individual must also recognize that the motive behind the act qualifies the crime. This legal knowledge and the necessary reporting skills transmitting this knowledge are by no means self-evident for a wide range of citizens nor should it not be their task. It is the experience of legal aid lawyers and NGOs providing victim support and representation, that in a significant number of cases law enforcement authorities only record the prejudice motive and the suspicion of a hate crime if specifically requested by the victim or other people assisting them during the criminal proceeding. ${ }^{8}$

One of the reasons for the inadequate application of the law is that a significant segment of the norms' addressees is unaware of the respective piece of legislation and its content, thus many victims lack the knowledge to bring the grievances to the attention of the authorities. In some cases, their advocacy capacity is also limited.

The ability of individuals to assert their rights and interests depends on a number of factors, including their level of education, place of residence, age, income and wealth, and their general interest towards public issues. Legal research also shows considerable variations across legal branches. ${ }^{9}$ The most thought-provoking aspect is that the level of legal knowledge decreases in conjunction with the decline of social status and the deterioration of income and property conditions. Consequently, complex multiple dimensional inequalities are formed. This deserves special attention for this topic because victims of hate crimes are often members of marginalized, multi-dimensionally disadvantaged groups. Some members of the potential victim groups do not have equal access to public goods, including access to justice. ${ }^{10}$

Optimists of the entitlement revolution ${ }^{11}$ forget to take into consideration that the burden of enforcing individual rights and claims largely falls on individuals. Enforcement requires complex resources and, in some cases, it is emotionally burdensome for an individual due to the personal involvement and terrifying effects. One of these burdens is taking on the victim role. This may not only be an emotional issue but in a significant number of hate crime cases, it requires disclosing an identity and, in extreme cases, accept and assume the consequences of stigmatization. Indeed, in many cases, the reporting of an individual rights infringement requires the identification with an unpopular social group ${ }^{12}$ or the classification of an individual as a group

\footnotetext{
${ }^{8}$ Dombos and Udvari (2014) 14.

${ }^{9}$ Podgórecki (1973) and Rooij (2020).

${ }^{10}$ See for example, Report about the implementation of Directive 2012/29/EU of the European Parliament and of the Council of 25 October 2012 establishing minimum standards on the rights, support and protection of victims of crime, and replacing Council Framework Decision 2001/220/JHA in Hungary, link 4.

${ }^{11}$ In connection with the unnoticed victims of discrimination from the past see, Assmann and Conrad (eds) (2010).

${ }^{12}$ See for example in connection with the Roma respondents Roma in the Czech Republic and Greece indicated the highest hate motivated harassment rate in the 12 months preceding the completion the Fundamental Rights Agency's survey (56\% and 50\%, respectively), while rates were lower for Roma in Bulgaria (12\%), Hungary (18\%) and Portugal (20\%). Only $10 \%$ of harassment victims said that they reported the most recent incident - either to the police or to another organisation/service. Amongst the reasons given for not reporting hate-motivated violence to police, researchers found for example that victims were not convinced that anything would happen or change by reporting ( $41 \%$ ), but $11 \%$ of the respondents mentioned not trusting the police or being afraid of the police as well. Link 5 .
} 
member in a disadvantaged group. ${ }^{13}$ Sometimes, protected characteristics are visible, but during an official procedure it is always needed to inform the authorities about them in order to provide the proper classification of crimes. The sense of shame and fear of outing are two significant phenomena related to the hate crimes' victims. Consequently, the gap between black-letter law and law in action is strikingly wide in this area even if compared to other fields of law. ${ }^{14}$

Victims often do not report crimes to the appropriate authorities as their emotions, previous experiences or the information they had gained from informal sources and distrust towards the authorities play an additional, significant role. Fear of secondary victimization, ${ }^{15}$ i.e. reexperiencing the grievances suffered during a criminal procedure, has a prominent role in this context. The alienating, hostile, sometimes humiliating, or even exclusionary nature of the process can have a significant devastating effect. ${ }^{16}$

One of the clearest proofs of the alienating effect of legal procedures is that citizens often feel to be only 'objects' in their own cases and not actors who can shape and organically transform the processes. They often have the well-founded perception that they are merely outside observers of events. ${ }^{17}$ The situation is much more serious if the party concerned is forced to suffer improper conduct by the authorities or, worse, discrimination. Occasionally, part of the law enforcement authority's work is affected by prejudicial attitudes and discriminatory behaviors towards minority groups. ${ }^{18,19}$ Research also suggests that victims may fear that the police sympathize with the offenders or that law enforcement will fail to empathize with them. ${ }^{20}$ Some victims may choose not to report hate crime because they believe that the police will not take them seriously or because they believe that the police will be unable to do anything. ${ }^{21}$ Distrust in public institutions and the representatives of public power, has also a significant effect. These phenomena will be discussed in detail in the second part of this paper.

\footnotetext{
${ }^{13}$ In the Hate No More project (LGBT sample) in 2015, a research was carried out in five Eastern and Central European countries. From the 168 Hungarian respondents, 37\% were victims of homophobic or transphobic incidents during the previous 5 years, while the reporting rate was only $23 \%$; and just $17 \%$ in case of the most serious incident of homophobic or transphobic violence or harassment. See more Iganski (2016) 15, 30.In the Uni-form project (LGBT sample) in 2016, research was conducted in 10 European countries. From the 348 Hungarian respondents, $46 \%$ have been already victims or witnesses of hate crimes because of sexual orientation or gender identity and $20 \%$ of the victims suffered physical violence. Only $10 \%$ of Hungarian respondents experiencing or witnessing homophobic or transphobic hate crimes or online hate speech reported it to the authorities. In the Uni-form project amongst the reasons given for not reporting homophobic or transphobic hate crimes to authorities, respondents mentioned that the official procedure would have no consequence (49\%), the case would not be handled seriously (40\%), feared a negative reaction from the police $(35 \%)$ and fear of jeopardizing the sexual orientation (27\%). Link 6.For some recent anti-LGBT hate crime researches, please also see: Godzisz and Viggiani (eds) (2019).

${ }^{14}$ In connection with the under-reporting and problems related to investigation, see Bárd and Bayer (2020).

${ }^{15}$ Herek, Cogan and Gillis (2002).

${ }^{16}$ For a more detailed description see, Uszkiewicz (2013b).

${ }^{17}$ Christie (1977).

${ }^{18}$ Atak (2019) 34.

${ }^{19}$ For example, related to the LGBT victim reluctance to contact law enforcement because of perceptions of police bias see, Briones-Robinson, Powers, Socia (2016).

${ }^{20} \mathrm{McD}$ evitt, Balboni, Bennett, Weiss, Orchowsky and Walbolt (2000).

${ }^{21}$ Sandholtz, Langton and Planty (2013).
} 
This phenomena and associated reasons have an effect on latency. This partly explains why official statistics are not able to provide a real and accurate picture of the prevalence and volume of hate crimes in Hungary or in most countries of the world. Of course, other legislative and law enforcement anomalies also play a role in deepening the problem of latency. ${ }^{22}$

\section{INSTITUTIONAL CAUSES}

This section focuses on the institutionalized reasons in connection with the shortcomings of hate crime investigations. The most well-known and best documented reasons behind the low effectiveness of investigations and proper legal classification will be presented. These include focusing on statistics when evaluating law enforcement agencies; prejudice of members of the police and public prosecution services towards members of typical victim groups; lack of knowledge on the law enforcement's side and lack of trainings. As a result of these issues, even if a crime eventually comes to the attention of the law enforcement authorities, there are still many obstacles that jeopardize an efficient investigation and a due prosecution of the crime.

\subsection{Incorrect selection of performance indicators}

The investigation of hate crime incidents requires special attention from the authorities and different methods than the investigation of ordinary crimes. ${ }^{23}$ Hate crimes often involve minority victims, police discretion, a necessary prerequisite, and the room of maneuver in allocating efforts can lead both to special policing attention but also to relative disadvantage as compared to conventional crime clearance. ${ }^{24}$ So, the police may have two opposite approaches to hate crimes. In some cases the police perceive hate crimes as more serious or deserving of special attention, so they allocate extra resources to investigate hate crime incidents and treat hate crimes with urgency acknowledging their increased gravity to both individual victims and the larger community. ${ }^{25}$ However, in some cases hate crimes may be disadvantaged as compared to ordinary crimes either due to additional hurdles in investigating hate crime incidents or because of the devaluation of the prototypically low status of hate crime victims. Victimdevaluation theorists, ${ }^{26}$ suggest that the distribution of 'quantity of law' is one aspect which determines the allocation of efforts and resources in individual cases from the law enforcement authorities and so it varies with the status of parties. Incidents involving lower status victims will receive 'less law'. ${ }^{27}$

Recent analyses have also shown that hate crimes are less likely than non-bias crimes to be reported to the police and that the police are less likely to take further action for hate crimes, compared to non-hate crimes. Researchers also found that those hate crimes are most likely to

\footnotetext{
${ }^{22}$ In connection with the high degree of latency also see, Bihariová (ed) (2018) 42-49.

${ }^{23}$ Related to the special vigilance from the European Court of Human Rights' practice, see Kirs, Hate crimes and international institutions: a literature review, in the present volume.

${ }^{24}$ Lyons and Roberts (2014).

${ }^{25}$ Lyons (2008).

${ }^{26}$ Black (1976).

${ }^{27}$ Swigert and Farrell (1977).
} 
result arrest which fit the profile of a 'stereotypical' hate crime: violent incidents, incidents committed by hate groups, and incidents involving White offenders and Black victims. ${ }^{28}$

Perceptions of the police (and the general public) ${ }^{29}$ related to hate crimes play an important role, either because of overt victim devaluation and diminished investigative effort or because third parties are less likely to come forward to provide quality evidence for incidents involving lower status victims. ${ }^{30}$

There are straightforward institutional reasons, as well as these systemic problems, for under-qualification. The most important reasons are the focus on statistics and the pressure to deliver results when evaluating the performance of police officers and public prosecutors. Investigators and prosecutors are not motivated to dwell into cases which require complicated pieces of evidence, if their professional performance is judged solely on the basis of

-how quick a policeman can efficiently close a case

-the percentage of cases where the prosecution presses on with the charges

-how effectively a public prosecutor can represent the charge before a judge

-the percentage of those suspects, who are ultimately convicted.

Such a system of evaluation prompts police officers to focus on cases that can be proven more easily. They neglect the hate motivation of a crime and conduct investigation only into the base crime, which requires no proof of the bias motive.

Furthermore, it has paramount importance of detecting potential bias motivation as early of the proceeding as possible and consequently obtaining all the supporting evidences. Obtaining this at a later stage could be proved just with difficulties or would be totally impossible. It has a crucial significance to flag every crime with potential hate motive at the earliest possible stage of a criminal procedure and conduct a proper investigation in all hate motivated acts. This is only way how the authorities can guarantee to find and collect all objective evidence of bias motivation. Front-line police officers are most likely to be the first respondent to an incident so their role is indispensable to understand the specific features of hate crimes and taking every practical step that could prove the bias motivation. ${ }^{31}$ Therefore, effective training for front-line officers who are likely to have first direct contact with victims and who are responsible for the first official report is crucial, at least they have to be aware of bias indicators. ${ }^{32}$

Similarly, public prosecutors are motivated to stay on the safe side and press charges in respect of the base crimes, even if the competent authorities conducted a proper and fully detailed investigation covering the possible bias motive.

In Hungary this statistical approach is combined with a special set of rules regarding the scope of authorities. If a local police unit does not qualify a case as a hate crime, it does not have to refer it to the county level. The county department where special knowledge is accumulated

\footnotetext{
${ }^{28}$ Lantz, Gladfelter and Ruback (2017).

${ }^{29}$ Lyons (2006).

${ }^{30}$ Cooney (1994).

${ }^{31}$ (OSCE): Understanding Anti-Semitic Hate Crimes and Addressing the Security Needs of Jewish Communities A Practical Guide. Link 7.

${ }^{32}$ Trickett and Hamilton (2016).
} 
and a hate crime unit is devoted to the investigation of bias crimes could take over these cases, but they are not aware of them. However, county departments are also not motivated to deal with hate crimes, consequently they try to keep away themselves from hard cases by not qualifying them as hate crimes because this way they can refer them back to the local level. As a result, all actors try to keep the simple cases and get rid of difficult ones. ${ }^{33}$

Police may face unique challenges in identifying and accurately classifying hate crimes compared to non-hate crimes, ${ }^{34}$ due to the 'ambiguity of applying legal definitions to cases, uncertainty regarding bias motivation, and infrequency of reported events to law enforcement'. ${ }^{35}$ Thus, authorities rather refrain from pressing on and investigating the hate motive.

\subsection{Political consequences ${ }^{36}$}

The Hate Crime Project at the University of Sussex has investigated the wider community impacts of hate crimes in the framework of a 5-year-long research project. Researchers found that hate crimes have substantial impacts that spread throughout targeted communities, such as anger, anxiety, feelings of threat and vulnerability, avoidance, security-related behaviors. In addition to the changed emotional and behavioral impacts, further community impacts include: negative perception of the police, and of law enforcement authorities, support of hate crime legislation and desire for the government to take more action. Those, who have only read about hate crimes express more empathy and solidarity towards the victims, and at the same time were more likely to express feelings of anger and anxiety compared to those who read about non-hate crimes. $^{37}$ People's behavioral responses to hate crimes were generally proactive in that respondents were much more likely to say that they would join community organizations and charities and use social media to raise awareness of hate crimes, rather than engaging in avoidance or retaliation-based conduct.

Hate crimes have significant costs in both the social and political domains.

Liberal democracies are based on equal human rights and their guarantees. A country which is perceived as not being able to protect their minority citizens gives an undesirable image. ${ }^{38}$ This is why an increasing number of hate crimes carry a political risk.

Hall pointed out that the social, political and historical context influences and shapes the creation of law, the mood of the public, and the law enforcement responses to social problems. ${ }^{39}$

\footnotetext{
${ }^{33}$ Dombos and Udvari (2014) 13.

${ }^{34}$ Nolan, Akiyama and Berhanu (2002).

${ }^{35}$ Cronin, McDevitt, Farrell and Nolan (2007).

${ }^{36}$ For a detailed analysis related to the political risks in Hungary, see, Bócz (2010) 378-83.

${ }^{37}$ Paterson, Walters, Brown and Fearn (2018) 10.

${ }^{38}$ The effect of the political discourse, narrative and rhetoric on the changes of the number of hate crimes is an independent question. For example, some scholars have argued that inflammatory statements by politicians seemingly supporting or condoning racist violence can contribute to hate crimes. In connection with this see more, Karapin (1999).For Trump's inflammatory rhetoric throughout the political campaign that caused hate crimes to increase, see for example Jenkins, available at link 8, or Edwards, Griffin Sims and Rushin, Stephen, The Effect of President Trump's Election on Hate Crimes (January 14, 2018). Available at link 9 or Müller, Karsten and Schwarz, Carlo, From Hashtag to Hate Crime: Twitter and Anti-Minority Sentiment (July 24, 2020). Available at link 10.
}

${ }^{39}$ Hall (2012). 
The inquiry into the murder of Stephen Lawrence, a well-known case, in February $1999^{40}$ placed the concept and politics of hate crime at the center of British politics. New legislation and police initiatives have begun to reconfigure the ways in which the criminal justice system dealt with bias crimes.

'Since the publication of the Stephen Lawrence Inquiry Report on 24 February 1999, there have been numerous initiatives, policy and guidance documents published, aimed at improving performance in some way across and within the criminal justice system. Though we note some small areas of progress, in light of the continued failings by the police service in relation to Black and minority ethnic recruitment, retention and progression and the disproportionate number of Black people being stop and searched, it is difficult to conclude that the charge of institutional racism no longer applies. ${ }^{41}$ All this suggests that the problem is still relativized by the competent authorities and not treated according to the gravity of the criminal behavior.

Bell recently argues, in relation to the political consequences, that specialized hate crime units in the 'Centre City' are forced to meet a double expectation: there is a pressure to enforce hate crime laws by advocacy groups and pressure not to enforce them by white working-class residents. Bell argued that there may actually be a disincentive for officers to identify bias: high hate crime rates reflect poorly on the community. ${ }^{42}$

\subsection{Lack of proper knowledge of the legislation}

Numerous awareness raising programs and training initiatives across Europe can be identified in the past years but further efforts need to be taken in order to increase the awareness amongst different police units including the higher police community. ${ }^{43}$ The number of reported hate crimes has increased in the recent years in Europe but the geographical differences are still significant. The obvious, well-known facts e.g. size of the population, migration, homo- or heterogeneous societies only partly explain these differences.

The Organization for Security and Co-operation in Europe (OSCE) clearly expressed that the reasons behind latency are often not deliberate attempts to ignore or underreport bias criminality but, rather, a lack of awareness of how to recognize and subsequently investigate, prosecute and sentence hate crimes. ${ }^{44}$ The Crown Prosecution Service, which is responsible for conducting criminal prosecutions in England and Wales, emphasized, in one of its latest annual hate crime reports, the relevance of enhancing working relations with community workers and improving awareness of how the law on hate crime works. ${ }^{45}$ The final comparative report of the eMORE project ${ }^{46}$ highlights amongst its recommendations that there is a need for the implementation of a joint circular system relating to investigation/prosecution policy regarding

\footnotetext{
${ }^{40}$ The Stephen Lawrence Inquiry: A report of an Inquiry, CM 4262-1, link 11.

${ }^{41}$ Rollock (2009).

${ }^{42}$ Bell (2002).

${ }^{43}$ Understanding the difference - The initial police response to hate crime (2018), link 12.

${ }^{44}$ (OSCE) Guide to Addressing Hate Crime at the Regional Level (2018), link 13.

${ }^{45}$ (Crown Prosecution Service) Hate Crime Annual Report 2017-18, link 14.

${ }^{46}$ Monitoring and reporting online hate speech in Europe.
} 
discrimination and hate crime, including the appointment of specialized hate crime police officers. ${ }^{47}$ In connection with this recommendation, some organizations emphasized that specialized units can increase the effectiveness of the investigative work related to hate crimes, contribute to a rise in the number of reported criminal offenses and provide special attention to the victims. ${ }^{48}$

Since 2011, every Hungarian county police department has had a professional hate crime expert ('rendórségi szakvonal és szakvonal tag') who is supposed to pay attention to criminal cases where there is a likelihood that a hate crime has occurred. ${ }^{49}$ The National Chief of Police order no. 30/2019. (VII. 18.) on the tasks of the police in relation to responding to hate crimes (revised Investigative Protocol) was issued in 2019 as a progressive initiative. This order includes a list of bias indicators that could be applied in hate crime cases and that could contribute to raising the standard of investigations and criminal procedures. The protocol specifies that a so-called 'mentor' must be appointed at each police station who helps to detect hate crimes; members of law enforcement and criminal personnel should be trained in bias indicators and county hate crime experts and the National Police Headquarters' line manager should monitor the ongoing criminal proceedings, media coverage related to hate crimes and the activities of organized hate groups. The order also talks about the professional trainings of Hungarian police officers, the annual meeting of hate crime specialists, the relevance of the victim support system and the importance of objective, victim-friendly communication. The adoption of this protocol can be seen as a significant progress, however its practical application can only be evaluated in the future.

\subsection{The technique of hate crime specific investigation is unknown}

One of the main obstacles to effective investigations is that law enforcement agents (mainly the police and the prosecutor's office) do not take into consideration the circumstances that indicate a hate crime in a particular case. The indicator-based investigation is unknown in many countries among law enforcement officers. This results in substandard investigations into the bias motive which again results in prosecutors under-qualifying hate crimes and bringing charges for less serious criminal offenses.

Bias indicators are objective facts, circumstances or patterns connected to a criminal act that, alone or in conjunction with other indicators, suggest that the offender's actions were motivated in whole or in part by bias, prejudice or hostility. ${ }^{50,51}$ The indicators on their own do not prove the motivation for prejudice but the presence of even one single indicator requires that the investigation should include the reconnaissance of the possible prejudice. Only an investigation covering all the specific circumstances of the crime can prove or exclude the existence of a prejudice motive. At the same time, bias indicators have a role both when searching for pieces of

\footnotetext{
${ }^{47}$ (eMORE) An overview on hate crime and hate speech in 9 EU countries. Towards a common approach to prevent and tackle hatred. Link 15 .

${ }^{48}$ See amongst other: (OSCE) Manual on joint hate crime training for police and prosecutors. Link 16. Against Hate: Guidebook of good practices in combating hate crimes and hate speech, link 17.(Amnesty International) Police and Minority Groups, link 18.

${ }^{49}$ Masked men attacked the Roma laborers just as the police officer had advised, link 19.

${ }^{50}$ (OSCE) Hate Crime Data-Collection and Monitoring Mechanisms - A Practical Guide (2014), link 20.

${ }^{51}$ (OSCE) Prosecuting Hate Crimes - A Practical Guide (2014), link 21.
} 
evidence pointing to bias at the crime scene and when reviewing evidence of a crime during the prosecution phase.

One of the latest EU Fundamental Rights Agency (FRA) reports shows that only 13 member states have lists with bias indicators that police officers can use to identify potential bias motivation(s) underlying a reported offense. These lists have two types: the publicly available list of bias indicators and the police internal list of bias indicators. ${ }^{52,53}$

Law enforcement officers must be able to use bias indicators to identify bias motivation. Any bias indicator that may provide evidence that the crime was committed out of social hatred should be taken into account.

However, examples show ${ }^{54}$ that the authorities are often unaware of these indicators and do not have appropriate knowledge of how to use them in order to prove the bias motivation, and/ or are not willing to attach significance to them. Numerous training materials are available but the relevance of these indicators during the criminal procedure stands out. The full list of indicators is published by OSCE in a practical guide, ${ }^{55}$ the most common and relevant ones are also listed by The International Association of Chiefs of Police (IACP). ${ }^{56}$ These are:

-perceptions of the victim(s) and witnesses about the crime

-the perpetrator's comments, gestures or written statements that reflect bias, including graffiti or other symbols

-any differences between perpetrator and victim, whether actual or perceived by the perpetrator -similar incidents in the same location or neighborhood to determine whether a pattern exists -the victim's engagement in activities promoting his/her group or community - for example, by clothing or conduct

-the incident coinciding with a holiday or data of particular significance

-involvement of organized hate groups or their members

-absence of any other motive such as economic gain.

Different indicators should be taken into account when the attack was committed against property and not against a person. These indicators include among others the following:

-property targeted has religious or other symbolic importance for a particular community, such as a church or a synagogue, a cemetery, or a monument commemorating the dead or celebrating historical figures from the community;

-property targeted is a center of community life, such as a school, social club or shop for a particular group;

-property targeted is different from surrounding property because it is owned or occupied by members of a particular community; and

-property has been the object of previous similar attacks.

\footnotetext{
${ }^{52}$ (FRA) Hate crime recording and data collection practice across the EU. Link 3.

${ }^{53}$ In connection with the indicators with concrete examples and relevant case studies see, Nolan, McDevitt, Cronin and Farrell (2004).

${ }^{54}$ See for example: Law enforcement problems in hate crime procedures. The experiences of the Working Group Against Hate Crimes in Hungary, link 22.

${ }^{55}$ (OSCE) Preventing and responding to hate crimes - A resource guide for NGOs in the OSCE region. Link 23.

${ }^{56}$ (IACP) Responding to Hate Crimes: A Police Officer's Guide to Investigation and Prevention. Link 24.
} 
A further typical weakness of investigations is that members of the authorities do not use all available investigative actions. Thorough searching of data about the personal background and history of the offender may be lacking. The possibilities of international legal aid are not exploited in cases where the offense or preparation is made by using foreign computer servers or due to different types of interpretation of freedom of expression, some foreign authorities do not respond to requests. 57,58

The Hungarian investigative protocol may also generate changes in this regard. It provides the possibility to conduct an open source data collection on the suspect's prejudices on the internet for the police officers investigating hate crime cases. Policepersons, can also cooperate with other law enforcement agencies, not mentioning, but not excluding, the possibility of cooperation with international organizations. Finally, among the bias indicators it lists the suspect's prejudiced attitude, which may be indicated by the programs/events they attended, their preferred bands, readings, and social media interface.

\subsection{Prejudice and institutional discrimination}

Everyday experience proves that people in most societies are prejudiced. A large majority of the law enforcement officers and some members of the judiciary are also biased. ${ }^{59}$ This bias has negative consequences for the guarantee of the rule of law and equality before the law. Moreover, standards against which institutional actors are held must always be higher than that for the average person: their exemplary behavior should be a reference point for everybody.

No law enforcement model and action can be effective without a satisfactory relationship between the police forces and citizens. This is also true for hate crimes. Effective and nondiscriminatory communication is a prerequisite for successful policing work, which requires increased vigilance and strong expertise. In case of hate crimes, it is particularly important that members of the police forces are able to show special attention to vulnerabilities and have an expertise in the communication with victims and witnesses. This requires knowledge of specific cultures, cultural patterns, respect for cultural diversity, knowledge of minority or foreign languages, and the ability of inter-cultural communication. In addition to impartial and fair treatment of victims, it is also necessary to employ specialized police forces, who are capable of acting in accordance with their special roles and expressing this in their communication, metacommunication and behavioral culture. Prejudiced officers obviously do not meet these criteria. $^{60}$

\footnotetext{
${ }^{57}$ Dombos and Udvari (2014) 12.

${ }^{58}$ Law enforcement problems in hate crime prosecutions. The experiences of the Working Group Against Hate Crimes in Hungary. Link 22.

${ }^{59}$ It is often cited, however, that for victims of racially motivated crimes, police mistreatment, abuse and brutal violence is a determining factor in a victim's decision to not report crimes to the police.'(ENAR): Racist crime \& institutional racism in Europe. ENAR Shadow Report 2014-2018, link 25.(FRA): Second European Union Minorities and Discrimination Survey Being Black in the EU, link 26.(Amnesty International): Policing the pandemic. Human rights violations in the enforcement of COVID-19 measures in Europe, link 27. Related to the Roma - police relationship in Hungary see, Héra (2017).

${ }^{60}$ In this regard, see in detail the results 'Conflict Resolution, Mediation and Restorative Justice and the Policing of Ethnic Minorities in Germany, Austria and Hungary’ (COREPOL) project, available at link 28.
} 
In general, discrimination in policing can be expressed internally (inside of the department) or externally (toward the public). Both supervisors and officers, moreover, can engage in discriminatory behavior. Discriminatory behavior by officers with an external focus can be passive (where officers withhold benefits or protections of the law) or active (where officers differentially enforce laws or department policies). ${ }^{61}$

Victims of hate crimes typically belong to a minority group or they are presumed by the perpetrator to be a minority citizen or resident. This means that the authorities involved in the investigation of hate crimes should be in contact with several members of the concerned minority group e.g. the victim, witnesses, other members of the group, such as family members, friends, relatives. It is therefore extremely important, in addition to the appropriate criminal classification, that the police officer appears to the victim as the bastion of rights protection. Victims' fear of the authorities will grow if they do not experience the same level of public service, as everyone else but suffer from inadequate responses from the authorities and its members during the criminal procedure, or if in the worst case, are openly receive discrimination. They will also be disappointed by the entire system of law enforcement and democratic institutions in general.

If 'institutional racism' is part of the police culture, it could have a profound effect on its operation and practices. In the most cases the victims of hate crimes belong to one of the minorities living in the affected country and it is crucial that members of the criminal justice system respect the principle of equality and non-discrimination and tackle all forms of racism. It was expressed in the 1999 Stephen Lawrence Inquiry that 'elimination of racist prejudice and the demonstration of fairness in all aspects of policing' is one of the solution-oriented aims of criminal justice. To 'increase trust and confidence in policing amongst minority ethnic communities' and to increase the number of law enforcement members in the organization with ethnic background are old proposals, that continue to gain in relevance. During the recruitment, progression and retention of police officers these aspects should also be taken into consideration.

The case-law of the European Court of Human Rights states that investigation authorities have a duty to assess pieces of evidence without bias. Law enforcement officers are obliged to respect the principle of non-discrimination and continue non-discriminatory investigations. ${ }^{62}$

There is also a positive sign in this context in the new Hungarian protocol as it states that police officers are obliged to communicate calmly, objectively, professionally, in a

\footnotetext{
${ }^{61}$ Kappeler, Sluder and Alpert (1994) 164.

${ }^{62}$ 'The ECHR addresses the prohibition of discrimination in its Article 14 and Protocol 12. Since hate crimes are extreme manifestations of discrimination, this provision has a special importance in dealing with the phenomenon of bias crime. At the time of writing the present study, a minority of EU MSs, notably 10 of them ratified Protocol 12. According to Article 14 ECHR "The enjoyment of the rights and freedoms set forth in this Convention shall be secured without discrimination on any ground such as sex, race, colour, language, religion, political or other opinion, national or social origin, association with national minority, property, birth or other status." As is apparent from the wording, Article 14 can only be invoked in conjunction with another Convention right. The relevant cases dealing with the repression of hate crimes effect mainly Article 2 of the ECHR on the right to life, Article 3 on the prohibition of torture and inhuman or degrading treatment beyond Article 14. In relation to crimes, the ECtHR developed long ago the doctrine of states' positive obligation to conduct effective investigations. In the past 15 years, however, it also formulated additional obligations on state parties to have penalty enhancements for hate crimes in their criminal codes, to show special vigilance to explore and unmask bias motives behind crimes, and to acknowledge mixed motives and protect those who can be associated with someone having a protected characteristic.' Link 29.
} 
victim-support way. Police officers must not display a personal judgment in relation to the victim's behavior, culture, origin, community, and must refrain from using words and phrases that are stereotypical, prejudicial, or suggestive of blaming the victim.

National good practices show that in countries such as Sweden, where the phenomenon is dealt with according to its relevance and importance in each and every case, the role of the police becomes unquestionable and esteemed. Exploration, handling of victims, correct labeling of the crime, its proper registration presupposes the adequate functioning and performance of the

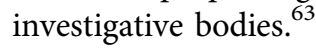

\subsection{The effect of hierarchy}

The devastating effects of institutional discrimination were described by an investigative committee in Milwaukee, U.S.:

'When the Dahmer investigation began in 1991, the MPD was headed by Chief Philip Arreola who had been in office for about two years. According to reports, Arreola was an advocate of communityoriented policing and attempted, with substantial resistance, to move the department in that direction. Because of the limited time Chief Arreola had spent in office, his ability to affect the department's environment, personnel, and operations was limited. Former Chief Harold Breier served in the department from 1940 to 1984; the long tenure had a substantial impact on the department. In fact, the Mayor's Citizen Commission (1991) noted that about three-fourths of the department's personnel, including most of those in command positions, had joined the force while Breier was chief. Breier's philosophy of policing was captured in a comment he made in August of 1991. The chief stated:

You can take community policing and stick it in your ear. There's no substitute for strong law enforcement. First, a police officer doesn't have the training to take care of all the social ills of the city. And second, he should be so busy maintaining law and order that he doesn't have time for that crap... When I was chief, we were relating to the good people, and we were relating to the other people too-we were throwing those people in the can .... I always said, 'The good people of Milwaukee, they bought what the Department was selling. ${ }^{\text {,64 }}$

In its report, the committee also pointed out that the pre-accession procedure had the same anti-democratic and racist aspects as the case under investigation. ${ }^{65}$

Brian Levin, a former New York City cop who heads the Center for the Study of Hate and Extremism at California State University, said what is particularly important is 'a clear message from the top of a police department that responding to hate crimes, and supporting the victims, is a priority. ${ }^{, 66}$

So, while the democratic and humane conduct of the police chiefs has a huge potential and can serve as role-model conduct, the opposite behavior can cause immeasurable damages.

\footnotetext{
${ }^{63}$ In connection with the Swedish example, see more, (Brå) Hate Crime 2009. Statistics of reports to the police where the motivation for crime includes ethnic background, religious faith, sexual orientation or transgender identity or expression. Link 30.

${ }^{64}$ Mayor's Citizen Commission (1991) 9 cited in Kappeler, Sluder and Alpert (1994) 158.

${ }^{65}$ For the details of the Dahmer massacre, see Milwaukee PD Criticized For Old Tweet Congratulating Cop Who Left Dahmer Victim, link 31.

${ }^{66}$ The Cities Where The Cops See No Hate, link 32.
} 


\section{CONCLUSIONS}

A comparison the official data of hate crimes with victims' rights surveys and data from alternative databases show an obvious high latency, which can be explained by a number of reasons. The aim of this literature review was to present these reasons, the difficulties and problems investigation authorities of hate crimes are facing. Proper reporting, investigation and prosecution related to these crimes requires a combination of special circumstances, while underreporting and underqualifying quite universally widespread. Barriers like lack of proper knowledge in how to report a crime or where to turn, distrust in law enforcement authorities, victim blaming, fear of secondary and re-victimisation, feelings of shame about being victimised, unwillingness to assume an identity openly, especially before authorities, language barriers, fear of jeopardizing illegal status, weak enforcement capacities are among the best documented personal reasons. However, this literature review analyses the institutionalized reasons behind the ineffectiveness of investigations and improper legal classification of hate crimes in a more detailed way e.g., the lack of understanding of what constitutes a hate crime, inadequate recognition of the different victim groups that may be targeted, lack of knowledge how to investigate a hate crime, institutional discrimination, improper way of performance evaluation of law enforcement authorities which may lead to impunity of perpetrators. These difficulties of enforcement in individual cases, also the specific interests of law enforcement agencies, but also, in a broader sense, the perspectives of the entire political community also contribute to the high latency. In light of the relevant literature, including scholarly and policy papers, reports from international and domestic organizations, agencies, authorities, monitoring organizations, civil society organizations, think tanks and research groups, as part of a wider analysis, this contributes to the understanding of the personal and institutionalized reasons of high latency.

A concluding summary can be provided by the OSCE: 'If police or prosecutors do not respond promptly to small-scale bias-motivated crimes (such as offensive graffiti), this sends the wrong message to both perpetrators and vulnerable groups. For perpetrators, a slow response provides them with an incentive to continue perpetrating such crimes; at the worst, it can increase the scale of bias-motivated crimes. For vulnerable groups, it reinforces feelings of fear, rejection and insecurity, thereby increasing the risk that communities will find ways to protect themselves or retaliate. Therefore, a prompt response to all bias-motivated crimes, regardless of their scale, is key to avoiding an escalation of the situation and shows that law enforcement agencies do care about and take such crimes seriously. ${ }^{67}$

\section{LITERATURE}

Assmann, A. and Conrad, S., (eds) Memory in a Global Age: Discourses, Practices and Trajectories (Palgrave Macmillan Memory Studies 2010).

Atak, K., '"Inappropriate but not crime"? Policing racial hatred in Sweden' (2019) 21 Nordic Journal of Criminology 32-48.

${ }^{67}$ (OSCE) Manual on Joint Hate Crime Training for Police and Prosecutors - Intended for use in Bulgaria. Link 33. 
Bárd, P. and Bayer, J., Hate speech and hate crime in the EU and the evaluation of online content regulation approaches (Policy Department for Citizens' Rights and Constitutional Affairs, Directorate-General for Internal Policies, 2020).

Bell, J., Policing hatred: Law enforcement, civil rights, and hate crime. (New York University Press 2002).

Bencze, M. and Vinnai E., (eds) Jogszociológiai előadások. Egyetemi jegyzet (Legal Sociological Lectures: University Textbook) (Debreceni Egyetem Állam- és Jogtudományi Kar 2012).

Bihariová, I., (ed) Tackling hate crime and hate speech in Europe (People in Need (Slovakia), The People for Change Foundation (Malta), Human Rights Monitoring Institute (Lithuania), Subjective Values Foundation (Hungary), In IUSTITIA, o.p.s (Czech Republic), 2018).

Black, D., The behavior of law (Academic Press 1976).

Bócz, E., Négy évtized az ügyészségen. Pályám emlékezete (Four Decades in the Prosecution Services. Memories of my vocation) (Pallas, 2010).

Briones-Robinson, R., Powers, R. A., and Socia, K., 'Sexual orientation bias crimes: Examination of reporting, perception of police bias, and differential police response' (2016) 43 Criminal Justice and Behavior 1688-1709.

Christie, N., 'Conflicts as Property' (1977) 17 The British Journal of Criminology 1-15.

Cooney, M., 'Evidence as partisanship' (1994) 28 Law \& Society Review 833-58.

Cronin, S. W., McDevitt, J., Farrell, A., and Nolan, J. 'Bias-crime reporting: Organizational responses to ambiguity, uncertainty, and infrequency in eight police departments' (2007) 51 The American Behavioral Scientist 213-31.

Dombos, T. and Udvari, M., Hate crimes in Hungary - Problems, recommendations, good practices (Másság Alapítvány 2014).

Godzisz, P. and Viggiani G., (eds) Awareness of Anti-LGBT Hate Crime in the European Union (Lambda Warsaw Association 2019).

Hall, N., 'Policing hate crime in London and New York City: Some reflections on the factors influencing effective law enforcement, service provision and public trust and confidence' (2012) 18 International Review of Victimology 73-87.

Héra, G., 'The relationship between the Roma and the police: a Roma perspective' (2017) 27 Policing and Society 393-407.

Herek, G. M., Cogan, J. C. and Gillis, J. R., 'Victim experiences in hate crimes based on sexual orientation' (2002) 58 Journal of Social Issues 319-39.

Iganski, P., Understanding the needs of persons who experience homophobic or transphobic violence or harassment: The impact of hate crime (Campaign Against Homophobia 2016).

Kappeler, V. E., Sluder, R. D. and Alpert, G. P., Forces of Deviance: Understanding the Dark Side of Policing (Waveland Press 1994).

Karapin, R., 'The politics of immigration control in Britain and Germany: subnational politicians and social movements' (1999) 31 Comparative Politics 423-44.

Kesteren, J. V., 'Assessing the risk and prevalence of hate crime victimization in Western Europe' (2016) 22 International Review of Victimology 139-60.

Lantz, B., Gladfelter, A.S., and Ruback, R. B., 'Stereotypical Hate Crimes and Criminal Justice Processing: A Multi-Dataset Comparison of Bias Crime Arrest Patterns by Offender and Victim Race' (2017) 36 Justice Quarterly 1-32.

Lyons, C. J., 'Stigma or Sympathy? Attributions of Fault to Hate Crime Victims and Offenders' (2006) 69 Social Psychology Quarterly 39-59.

Lyons, C. J., 'Individual perceptions and the social construction of hate crime' (2008) 45 The Social Science Journal 107-31. 
Lyons, C. J. and Roberts A., 'The Difference "Hate" Makes in Clearing Crime: An Event History Analysis of Incident Factors' (2014) 30 Journal of Contemporary Criminal Justice 268-89.

McDevitt, J., Balboni, J. M., Bennett, S., Weiss, J. C., Orchowsky, S., and Walbolt, L., 'Improving the quality and accuracy of bias crimes nationally: An assessment of the first ten years of bias crime data collection' (2000) (Washington, DC: U.S. Bureau of Justice Statistics, reprinted in Perry, B. (ed), Hate and bias crime: A reader Routledge 2003 77-89).

Nolan, J., Akiyama, Y. and Berhanu, S., 'The Hate Crime Statistics Act of 1990. Developing a Method for Measuring the Occurrence of Hate Violence' (2002) 46 American Behavioral Scientist 136-53.

Nolan, J.J., III, McDevitt, J., Cronin, S. and Farrell, A. 'Learning to See Hate Crimes: A Framework for Understanding and Clarifying Ambiguities in Bias Crime Classification' (2004) 17 Criminal Justice Studies 91-105.

Paterson, J., Walters, M. A., Brown, R. and Fearn H., The Sussex Hate Crime Project - Final Report (University of Sussex, 2018).

Podgórecki, A. et al., Knowledge and Opinion about Law (Martin Robertson 1973).

Rollock, N., The Stephen Lawrence Inquiry 10 Years On. An Analysis of the Literature (Runnymede, 2009).

Rooij, B. van., 'Do people know the law? Empirical evidence about legal knowledge and its implications for compliance' (2020) Legal Studies Research Paper Series No. 2020-22.

Sandholtz, N., Langton, L., and Planty, M., Hate crime victimization, 2003-2011 (Washington DC: Bureau of Justice Statistics 2013).

Swigert, V. and Farrell, R., 'Normal homicides and the law' (1977) 42 American Sociological Review 16-32.

Trickett L. and Hamilton, P., Hate Crime Training of Police Officers in Nottingham: A Critical Review (Nottingham Law School, Nottingham University 2016).

Uszkiewicz, E., 'Mit (nem) mutatnak a számok?' (What the Numbers [Fail to] Show?) (2013a) 61 Belügyi Szemle 84-91.

Uszkiewicz, E., 'Rendőri segítséggel? Hatással van-e a gyülölet-büncselekményekkel kapcsolatos nyomozati munkára a rendőrségi diszkrimináció?' (With Police Assistance? Does Police Discrimination Affect Detective Work Concerning Hate Crimes?) (2013b) 17 Fundamentum 38-46.

\section{LINKS}

Link 1: <https://hatecrime.osce.org/ $\geq$ accessed 27 October 2020.

Link 2: <https://fra.europa.eu/sites/default/files/fra-2012_hate-crime.pdf $\geq$ accessed 27 October 2020.

Link 3: <https://fra.europa.eu/sites/default/files/fra_uploads/fra-2018-hate-crime-recording_en.pdf $\geq$ accessed 27 October 2020.

Link 4: <https://en.hatter.hu/sites/default/files/dokumentum/kiadvany/hatter-aldozatvedatultet-eng.pdf $\geq$ accessed 27 October 2020.

Link 5: <https://fra.europa.eu/sites/default/files/fra_uploads/fra-2017-eu-midis-ii-main-results_en.pdf $\geq$ accessed 27 October 2020.

Link 6: <https://hatter.hu/sites/default/files/dokumentum/kiadvany/uniform-osszefoglalo.pdf $\geq$ accessed 27 October 2020.

Link 7: <https://www.osce.org/files/f/documents/c/c/317166.pdf $\geq$ accessed 27 October 2020.

Link 8: <https://archive.thinkprogress.org/thinkprogress-has-been-tracking-hate-since-trumps-electionhere-s-what-we-found-e0288ed69869/ $\geq$ accessed 27 October 2020. 
Link 9: <https://ssrn.com/abstract $=3102652 \geq$ accessed 27 October 2020.

Link 10: $<$ https://ssrn.com/abstract $=3149103 \geq$ accessed 27 October 2020.

Link 11: <https://assets.publishing.service.gov.uk/government/uploads/system/uploads/attachment_data/ file/277111/4262.pdf $\geq$ accessed 27 October 2020.

Link 12: <https://www.justiceinspectorates.gov.uk/hmicfrs/wp-content/uploads/understanding-thedifference-the-initial-police-response-to-hate-crime.pdf $\geq$ accessed 27 October 2020.

Link 13<: https://www.osce.org/odihr/402536?download=true $\geq$ accessed 27 October 2020.

Link 14: <http://www.report-it.org.uk/files/cps-hate-crime-report-2018_1.pdf $\geq$ accessed 27 October 2020.

Link 15: <https://www.rissc.it/wp-content/uploads/2020/06/AN_OVERVIEW_ON_HATE_CRIME_ AND_HATE_SPEEC.pdf $\geq$ accessed 27 October 2020.

Link 16: <https://www.osce.org/files/f/documents/3/b/402296.pdf $\geq$ accessed 27 October 2020.

Link 17: <https://yhdenvertaisuus.fi/documents/5232670/13949561/Opas+hyvist\%C3\%A4+k\%C3\%A4yt\% C3\%A4nn\%C3\%B6ist\%C3\%A4/2f0621c0-009b-9d31-4d38-0119913ffea4/Opas+hyvist\%C3\%A4+k\% C3\%A4yt\%C3\%A4nn\%C3\%B6ist\%C3\%A4.pdf $\geq$ accessed 27 October 2020.

Link 18: <https://www.amnesty.nl/content/uploads/2017/02/ainl_police_and_minority_groups_eng_0. pdf?x45368 $\geq$ accessed 27 October 2020.

Link 19: <https://budapestbeacon.com/masked-men-attacked-roma-laborers-just-police-officer-advised/ $\geq$ accessed 27 October 2020.

Link 20: <https://www.osce.org/odihr/datacollectionguide?download=true $\geq$ accessed 27 October 2020.

Link 21: <https://www.osce.org/files/f/documents/0/0/124532.pdf $\geq$ accessed 27 October 2020.

Link 22: <http://gyuloletellen.hu/sites/default/files/ejk_casesummary.pdf $\geq$ accessed 27 October 2020.

Link 23: <https://www.osce.org/odihr/39821?download=true $\geq$ accessed 27 October 2020.

Link 24: <https://www.theiacp.org/resources/responding-to-hate-crimes-a-police-officers-guide-toinvestigation-and-prevention $\geq$ accessed 27 October 2020.

Link 25: <https://www.enar-eu.org/IMG/pdf/shadowreport2018_final.pdf $\geq$ accessed 27 October 2020.

Link 26: <https://fra.europa.eu/sites/default/files/fra_uploads/fra-2018-being-black-in-the-eu_en.pdf $\geq$ accessed 27 October 2020.

Link 27: <https://www.amnesty.org/download/Documents/EUR0125112020ENGLISH.PDF $\geq$ accessed 27 October 2020.

Link 28: <https://www.corepol.eu/ $\geq$ accessed 27 October 2020.

Link 29: <https://www.europarl.europa.eu/RegData/etudes/STUD/2020/655135/IPOL_STU(2020)655135_ EN.pdf $\geq$ accessed 27 October 2020.

Link 30: <http://www.red-network.eu/resources/toolip/doc/2012/01/13/hate-crimes-in-sweden-2009.pdf $\geq$ accessed 27 October 2020.

Link 31: <https://www.newsweek.com/milwaukee-pd-congratulate-retired-cop-who-laughed-off-teenvictim-dahmer-1512130 $\geq$ accessed 27 October 2020.

Link 32: <https://www.buzzfeednews.com/article/peteraldhous/hate-crimes-miami-police-irving-syracuse $\geq$ accessed 27 October 2020.

Link 33: <https://www.osce.org/odihr/385035?download=true $\geq$ accessed 27 October 2020.

Open Access. This is an open-access article distributed under the terms of the Creative Commons Attribution 4.0 International License (https://creativecommons.org/licenses/by/4.0/), which permits unrestricted use, distribution, and reproduction in any medium, provided the original author and source are credited, a link to the CC License is provided, and changes - if any - are indicated. (SID_1) 